\title{
Optimization of hot-air drying conditions on functional properties of flour from dried South African sweet potato cultivars (Impilo and Bophelo) using the response surface methodology
}

\author{
Phuti Itumeleng MOLOTO ${ }^{1,2 *}$, Mmathaha MOSALA ${ }^{2}$, Adewale Olusegun OMOLOLA $^{1}$ (D), \\ Afam Israel Obiefuna JIDEANI ${ }^{1,3}$ (D), Sunette Marlize LAURIE² ${ }^{(D)}$
}

\begin{abstract}
The response surface method (RSM) has an important application in formulation of new products. This study determined the effect of electric hot-air drying on the functional properties of flour made from orange-fleshed sweet potato (OFSP). Flour from the cultivars Bophelo (B) and Impilo (IM) were treated with 13 temperature-time combinations designed by STAT EASE software version 8.01.0. Bophelo flour dried at $70{ }^{\circ} \mathrm{C}$ for $8.6 \mathrm{hrs}$ and Impilo at $70^{\circ} \mathrm{C}$ for $14.4 \mathrm{hrs}$ showed the lowest gelatinization temperatures and enthalpy of gelatinization $(\Delta \mathrm{H})$, indicating ease of cooking. The highest swelling power of $12.45 \mathrm{~g} / \mathrm{g}$ for Bophelo and $8.16 \mathrm{~g} / \mathrm{g}$ for Impilo were significantly higher than the remaining samples. Flours for Bophelo and Impilo at drying temperatures and times at $70^{\circ} \mathrm{C}$ for $4.4 \mathrm{hrs}, 56^{\circ} \mathrm{C}$ for $6.5 \mathrm{hrs}$ and $60^{\circ} \mathrm{C}$ for $6.5 \mathrm{hrs}$ indicated favourable gelling properties and cost of drying, implying that these can be used at household level and in food industries as thickeners from both cultivars.
\end{abstract}

Keywords: orange fleshed sweet potato flour; cabinet drier; pasting properties; gelatinization; swelling and solubility.

Practical Application: Nutritional and health benefits of orange-fleshed sweet potatoes.

\section{Introduction}

Rheological and functional properties are physico-chemical properties which provide data on how a specific ingredient (e.g. starch, protein) will perform in a food system (Mohamed et al., 2019). Starch as a component of sweet potato can be set up to show useful properties with potential utility in certain food applications (Allen et al., 2012; Ahmed et al., 2010). However, other constituents such as sugars, lipids, and amylases influence the functional behaviour of sweet potato starch during processing. These properties can be standardized by controlling the rate of heating during cooking which activates endogenous amylolytic enzymes in the sweet potato root to change a portion of the starch to dextrins. Measuring gelatinization characteristics of food is extremely relevant in food processing on the grounds that it permits reproduction of the cooking procedure for enhanced functional properties. In flour production, pasting properties is a vital index in determining where the flour can be best applied.

Orange-fleshed sweet potato (OFSP) has been adopted in many regions of Sub-Saharan Africa as a means to address vitamin A deficiency (Parker et al., 2019). Increased processing of OFSP contributes towards improved food security, nutrition and increased food variety (Owade et al., 2018). Drying has become a widely used way of food processing, allowing the extension of the shelf life by the physical removal of water, for example, by hot air drying (Kamal et al., 2013; Oke \& Workneh, 2013; Rufus, 2012). Hot air drying has the advantage of lower energy consumption, is lower in cost, and can be better controlled than other drying methods. In previous studies, the effect of variety and processing method on the functional properties of traditional sweet potato flour ("elubo") and sensory acceptability of cooked paste ("amala") was evaluated (Fetuga et al., 2014). The effects of peeling, drying temperatures, and sulphite-treatment on the physicochemical properties and nutritional quality of SP flour have been assessed (Ahmed et al., 2010). Olutande et al. (2016) observed that the interactive effect of variety, pretreatment, and drying method had a significant effect on quality attributes of OFSP flour.

The response surface method (RSM) has important applications in the design, development and formulation of new products, as well as in the improvement of existing product design. RSM was used to optimize the hot air drying process, considering drying temperature and time and their interactions in the quality evaluation of dried flour (Omolola et al., 2015; Manjarres-Pinzon et al., 2012), and in assessing the effect of date syrup and sugars on the rheological and pasting properties of sweet potato and corn starch gel (Mohamed et al., 2019). Other researchers used the methodology with OFSP, optimizing conditions for vacuum frying of chips (Esan et al., 2015) and pasta production (Singh et al., 2004).

The aim of this study was to assess the effect of hot air drying on the physico-chemical quality of OFSP flour from two South African cultivars. 


\section{Materials and methods}

\subsection{Samples preparation of the flour}

Two OFSP cultivars, Impilo (IM) and Bophelo (B), were obtained from the Agricultural Research Council-Vegetable and Ornamental Plants (ARC-VOP), Pretoria (Roodeplaat) in South Africa. OFSPs were sorted and washed manually with water. An electric industrial potato peeler was used to peel the OFSP, which were sliced into $2-3 \mathrm{~mm}$ thick slices using a vegetable cutter. The slices were blanched in an open steam cooker, followed by soaking in water (1:2) containing $1000 \mathrm{ppm}$ sulphur dioxide for $20 \mathrm{~min}$ (Abdulla et al., 2014). The sulphited cubes were drained, loaded in trays $(6 \mathrm{~kg} / \mathrm{m} 2)$, and dried using a range of 13 different temperature $\left({ }^{\circ} \mathrm{C}\right)$ and time (hrs) treatments designed by STAT EASE software version 9.0: at $70^{\circ} \mathrm{C}$ for $6.5 \mathrm{hrs}$; $70{ }^{\circ} \mathrm{C}$ for $8.6 \mathrm{hrs} ; 80{ }^{\circ} \mathrm{C}$ for $5 \mathrm{hrs} ; 70{ }^{\circ} \mathrm{C}$ for $6.5 \mathrm{hrs} ; 70{ }^{\circ} \mathrm{C}$ for $4.4 \mathrm{hrs} ; 80^{\circ} \mathrm{C}$ for $8 \mathrm{hrs} ; 60^{\circ} \mathrm{C}$ for $8 \mathrm{hrs} ; 70^{\circ} \mathrm{C}$ for $6.5 \mathrm{hrs} ; 70{ }^{\circ} \mathrm{C}$ for $6.5 \mathrm{hrs}$ : $56^{\circ} \mathrm{C}$ for $6.5 \mathrm{hrs} ; 60^{\circ} \mathrm{C}$ for $5 \mathrm{hrs} ; 70{ }^{\circ} \mathrm{C}$ for $6.5 \mathrm{hrs}$; and $84^{\circ} \mathrm{C}$ for $6.5 \mathrm{hrs}$. The flour was obtained by milling the dried cubes in a hammer mill to an average particle size of $300 \mu \mathrm{m}$.

\subsection{Pasting properties}

Pasting properties was determined using a Rapid Visco Analyser (RVA), model 3 D (Newport Scientific Pty Ltd., Warri wood NSW 2102, Australia). Flour (3.41 g) was suspended (dry basis) in $25 \mathrm{~mL}$ of distilled water and it was heated from 50 to $95^{\circ} \mathrm{C}$ at a rate of $12{ }^{\circ} \mathrm{C} / \mathrm{min}$, with constant stirring at $160 \mathrm{rpm}$ and held at $95^{\circ} \mathrm{C}$ for $2.5 \mathrm{~min}$ (break down), then cooled to $50^{\circ} \mathrm{C}$ at a rate of $13^{\circ} \mathrm{C} / \mathrm{min}$ (set back) and held for $2 \mathrm{~min}$. The total cycle was 13 min (Fetuga et al., 2014; Nabubuya et al., 2012). Pasting temperature was recorded as the temperature at which an increase in viscosity was first observed. The values that were reported include pasting temperature $\left({ }^{\circ} \mathrm{C}\right)$, peak viscosity (measured in Rapid-Visco Analyser units (RVU)), final viscosity (RVU), trough (lowest viscosity, RVU), break down (the difference between peak viscosity and trough, RVU), set back from peak (the difference between final viscosity and peak viscosity, RVU) and setback from trough (the difference between final viscosity and trough, RVU) (Fetuga et al., 2014).

\subsection{Swelling and solubility}

Swelling power and solubility patterns were determined as described by Ahmed et al. (2010). Flour ( $0.5 \mathrm{~g}$ ) was suspended in $25 \mathrm{~mL}$ of water for $30 \mathrm{~min}$ at a temperature of $90^{\circ} \mathrm{C}$ using a water bath. Subsequently, the mixture was centrifuged at $2000 \mathrm{rpm}$ for $15 \mathrm{~min}$, the clear supernatant carefully drawn off by suction into a porcelain dish, oven dried at $105^{\circ} \mathrm{C}$ for $24 \mathrm{hrs}$, and then weighed. The insoluble residues were also weighed. The difference in weight of the soluble starch and sample was used to calculate the water solubility. Swelling power was obtained by weighing the residue after centrifugation and dividing by the original weight of the flour on a dry weight basis (Ahmed et al., 2010; Aina et al., 2009).

\subsection{Differential scanning calorimetry}

Differential scanning calorimetry (DSC) was carried out with a Mettler DSC- 30 instrument, equipped with STARe software. The PT-sensor was calibrated using Indium. Samples $(20 \mathrm{mg})$ were accurately weighed, mixed with water $(1: 3 \mathrm{w} / \mathrm{w})$ and were placed into standard aluminium crucibles. The crucibles were crimpled and heated from $20-100^{\circ} \mathrm{C}$ for all flour samples at a scanning rate of $10^{\circ} \mathrm{C} / \mathrm{min}$. An empty crucible with a pierced lid was used as a reference. A minimum of three measurements were performed for each sample. Both gelatinization temperature and enthalpy values of flour samples were recorded (Rohaya et al., 2013); Jonathan et al., 2012).

\subsection{Statistical analysis}

The experiment was designed as a completely randomized design (CRD) with 13 samples for each of the two OFSP cultivars (Bophelo and Impilo), replicated three times. The response surface methodology (RSM) data was analysed using a commercial statistical package, Design-Expert version 8.0.1.0 (Statease Inc., Minneapolis, USA). The software was used for analysis of variance (ANOVA), regression analysis, and optimization (Akinoso \& Adeyanju, 2012). The numerical optimization of the drying process was aimed at finding the optimum drying temperature and time. ANOVA was used at the 0.05 significance level. Experimental data were fitted to linear, cross-product and second order polynomial models for pasting properties, swelling and solubility index, gelatinization parameters, colour, $\beta$-carotene content and vitamin $\mathrm{C}$ content as a function of drying temperature and time. Mathematical models were evaluated for each response by means of multiple regression analysis. The model adequacies were checked by fitted $\mathrm{R}^{2}$, F-value, $\mathrm{P}$-value, and the sum of squares model (Manjarres-Pinzon et al., 2012).

\section{Results and discussion}

\subsection{Pasting properties of Bophelo (B) and Impilo (IM) flour}

Pasting properties of the flours from the two OFSP varieties varied significantly $(\mathrm{p}<0.05)$ (Table 1 and Table 2 ). Impilo and Bophelo flour, ranging from 837.67 to $1042.67 \mathrm{cP}$ and from 1239.04 to $1301.16 \mathrm{cP}$, respectively, showed high peak viscosity, implying suitability for the production of products requiring high gel strength, thick paste and elasticity, and is an indication of high starch content (Adebowale et al., 2005; Shimelis et al., 2006). Setback of some IM samples ranging from 155.67 to $197.00 \mathrm{cP}$ was lower than some of the remaining samples (219.67 to $434.67 \mathrm{cP})$. While for samples Bophelo, B1, B4, B8 and B9 ( 407.33 to $474.00 \mathrm{cP}$ ) a high setback was observed, while the rest of the samples showed low setback (203.67 to $344.33 \mathrm{cP}$ ). According to literature, low set back means good gelling properties (Okafor \& Ugwu, 2013) and high setback means a low ability to withstand heat and shear stress during cooking and leads to a week gel (Nabubuya et al., 2012). Trough values for flour in this study varied for IM from $371.67 \mathrm{cP}$ to $1004.67 \mathrm{cP}$, and for B from 373.67 to $1186.67 \mathrm{cP}$, as shown in Table 1 and Table 2. The samples for Bophelo showed low breakdown values, ranging from 18.67 to $66.33 \mathrm{cP}$, except for B5, B7 and B10, which had high breakdown values. Impilo flour (34.00 to $92.33 \mathrm{cP}$ ) had low breakdown values, while IM5, IM7, IM10 and IM11 exhibited high breakdown values $(115.67$ to $144.33 \mathrm{cP})$. This indicates that starches with high breakdown values are likely to produce unstable pastes (Singh et al., 2006).

Pasting temperature of most Impilo flour samples was high $\left(70.74{ }^{\circ} \mathrm{C}\right.$ to $\left.89.46^{\circ} \mathrm{C}\right)$, as compared to $\operatorname{IM} 13\left(59.70{ }^{\circ} \mathrm{C}\right)$. 
Moloto et al.

Table 1. Pasting properties for Bophelo flour at various temperature and time drying conditions.

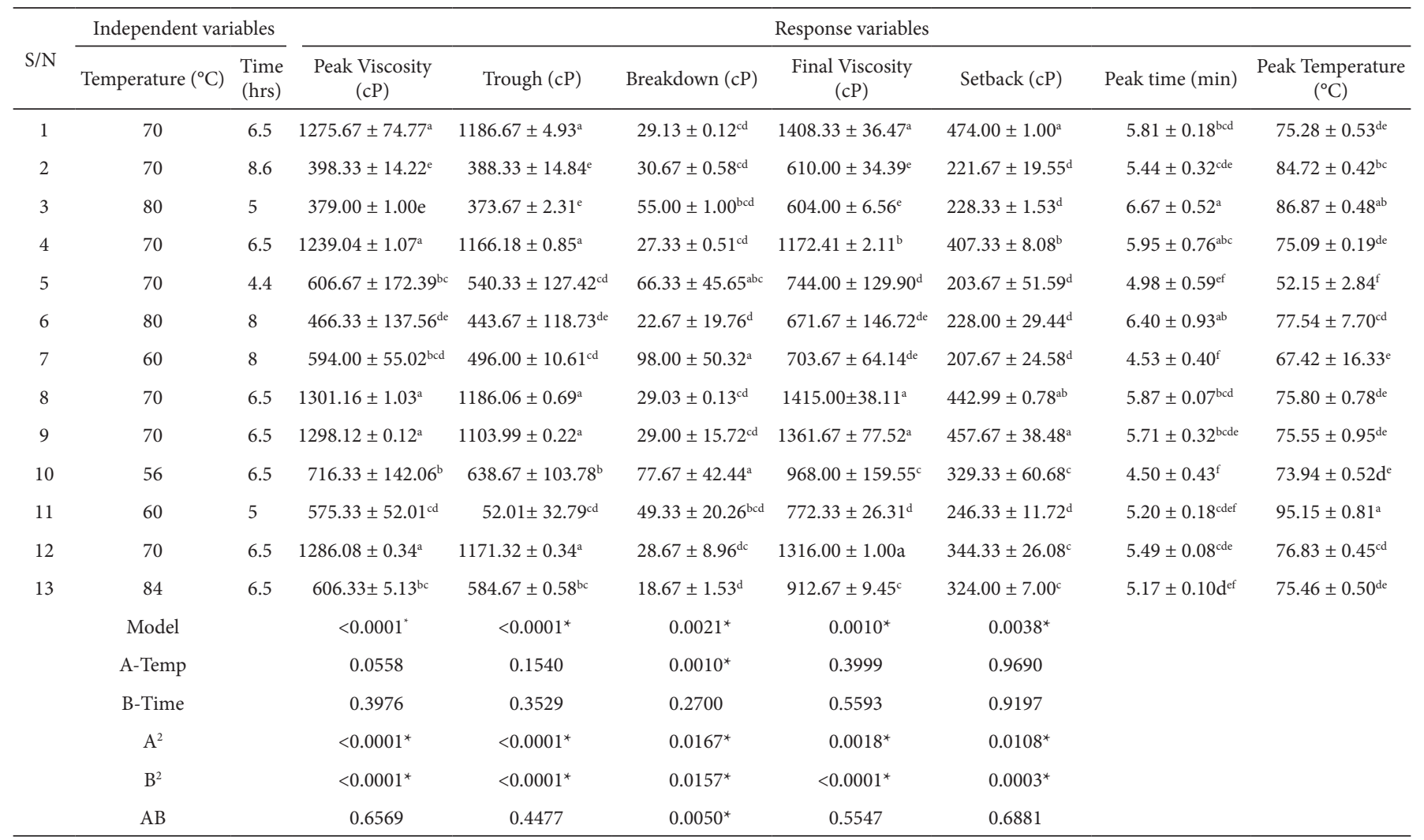

Mean \pm standard deviation; Means with similar superscript letters in a column do not differ significantly $(\mathrm{p}<0.05)$. ${ }^{*}$ Significant at $\mathrm{p}<0.05$. A: direct effect of drying temperature; B: direct effect of drying time; $\mathrm{AB}$ : effect of drying temperature and drying time; $\mathrm{A}^{2}$ : quadratical effect of drying temperature; $\mathrm{B}^{2}$ : quadratical effect of drying time; $\mathrm{S} / \mathrm{N}$ : Sample number.

Table 2. Pasting properties for Impilo flour at various temperature and time drying conditions.

\begin{tabular}{|c|c|c|c|c|c|c|c|c|c|}
\hline \multirow[b]{2}{*}{$\mathrm{S} / \mathrm{N}$} & \multicolumn{2}{|c|}{ Independent variables } & \multicolumn{7}{|c|}{ Response variables } \\
\hline & Temperature $\left({ }^{\circ} \mathrm{C}\right)$ & $\begin{array}{l}\text { Time } \\
\text { (hrs) }\end{array}$ & $\begin{array}{l}\text { Peak Viscosity } \\
(\mathrm{cP})\end{array}$ & Trough (cP) & Breakdown (cP) & $\begin{array}{l}\text { Final Viscosity } \\
(\mathrm{cP})\end{array}$ & Setback (cP) & Peak Time (min) & $\begin{array}{c}\text { Peak Temperature } \\
\left({ }^{\circ} \mathrm{C}\right)\end{array}$ \\
\hline 1 & 70 & 6.5 & $812.00 \pm 5.00^{f}$ & $767.67 \pm 12.34^{\mathrm{d}}$ & $34.00 \pm 2.00^{\mathrm{g}}$ & $1119.33 \pm 0.58^{\mathrm{e}}$ & $349.33 \pm 1.15^{\mathrm{d}}$ & $5.41 \pm 0.03^{c}$ & $77.13 \pm 0.55^{\mathrm{g}}$ \\
\hline 2 & 70 & 8.6 & $452.00 \pm 7.21^{\mathrm{k}}$ & $371.67 \pm 6.66^{1}$ & $77.00 \pm 1.00^{\mathrm{d}}$ & $547.00 \pm 18.06^{\mathrm{k}}$ & $163.67 \pm 5.56^{j}$ & $3.94 \pm 0.04^{\mathrm{h}}$ & $83.74 \pm 0.40^{\mathrm{b}}$ \\
\hline 3 & 80 & 5 & $837.67 \pm 3.21^{\mathrm{e}}$ & $786.00 \pm 5.29^{c}$ & $54.33 \pm 0.58^{\mathrm{e}}$ & $1093.00 \pm 5.20^{\mathrm{f}}$ & $310.33 \pm 0.58^{\mathrm{e}}$ & $5.52 \pm 0.13^{\mathrm{bc}}$ & $81.83 \pm 0.29^{c d}$ \\
\hline 4 & 70 & 6.5 & $1042.67 \pm 2.52^{\mathrm{a}}$ & $1004.67 \pm 1.53^{\mathrm{a}}$ & $42.00 \pm 2.65^{\mathrm{fg}}$ & $1438.67 \pm 3.21^{\mathrm{b}}$ & $434.67 \pm 4.04^{\mathrm{a}}$ & $5.55 \pm 0.17^{\mathrm{b}}$ & $77.34 \pm 0.21^{\mathrm{fg}}$ \\
\hline 6 & 80 & 8 & $608.67 \pm 2.52^{\mathrm{h}}$ & $517.33 \pm 4.93^{\mathrm{i}}$ & $92.33 \pm 0.58^{c}$ & $735.33 \pm 3.51^{\mathrm{g}}$ & $219.67 \pm 2.08^{g}$ & $4.57 \pm 0.03^{\text {ef }}$ & $79.60 \pm 0.53^{\mathrm{e}}$ \\
\hline 7 & 60 & 8 & $510.00 \pm 5.00^{j}$ & $491.67 \pm 3.06$ & $115.67 \pm 1.53^{\mathrm{b}}$ & $712.00 \pm 3.00^{\mathrm{h}}$ & $231.67 \pm 16.07^{\mathrm{f}}$ & $5.41 \pm 0.03^{c}$ & $89.46 \pm 0.28^{\mathrm{a}}$ \\
\hline 8 & 70 & 6.5 & $866.67 \pm 4.93^{\mathrm{d}}$ & $706.33 \pm 5.51^{\mathrm{g}}$ & $47.81 \pm 0.30^{\mathrm{ef}}$ & $1476.72 \pm 0.41^{\mathrm{a}}$ & $376.67 \pm 2.52^{\mathrm{b}}$ & $4.69 \pm 0.10^{e}$ & $82.65 \pm 0.38^{c}$ \\
\hline 9 & 70 & 6.5 & $887.67 \pm 3.21^{\mathrm{g}}$ & $737.00 \pm 4.36^{\mathrm{e}}$ & $52.00 \pm 1.00^{\mathrm{e}}$ & $1379.14 \pm 0.11^{c}$ & $347.67 \pm 1.53^{\mathrm{d}}$ & $4.48 \pm 0.10^{\mathrm{f}}$ & $81.80 \pm 0.27^{\mathrm{d}}$ \\
\hline 10 & 56 & 6.5 & $623.79 \pm 0.20^{\mathrm{g}}$ & $548.33 \pm 0.38^{\mathrm{h}}$ & $120.00 \pm 16.64^{\mathrm{b}}$ & $657.32 \pm 0.60^{\mathrm{i}}$ & $197.00 \pm 2.65^{\mathrm{h}}$ & $4.52 \pm 0.05^{\mathrm{f}}$ & $70.74 \pm 0.47^{\mathrm{i}}$ \\
\hline \multirow{6}{*}{13} & Model & & 0.0126 & $0.0074^{*}$ & $0.0014^{*}$ & $0.0081^{*}$ & $0.0092^{*}$ & & 0.0755 \\
\hline & A-Temperature & & 0.1132 & $0.0463^{*}$ & $0.0022^{*}$ & 0.5985 & 0.7455 & & 0.2404 \\
\hline & B-Time & & 0.4964 & 0.2775 & 0.0969 & 0.4852 & 0.5726 & & 0.2366 \\
\hline & $\mathrm{A}^{2}$ & & 03314 & $0.0448^{*}$ & $0.0073^{*}$ & $0.0021^{*}$ & $0.0028^{*}$ & & $0.0351^{*}$ \\
\hline & $\mathrm{B}^{2}$ & & $0.0009^{*}$ & $0.0012^{*}$ & $0.0007^{*}$ & $0.0028^{*}$ & $0.0026^{*}$ & & 0.1600 \\
\hline & $\mathrm{AB}$ & & 0.4743 & 0.0966 & 0.0754 & 0.2278 & 0.2272 & & 1.1461 \\
\hline
\end{tabular}

Mean \pm standard deviation; Means with similar superscript letters in a column do not differ significantly $(\mathrm{p}<0.05)$. ${ }^{*}$ Significant at $\mathrm{p}<0.05$. A: direct effect of drying temperature; B: direct effect of drying time; $A B$ : effect of drying temperature and drying time; $A^{2}$ : quadratical effect of drying temperature; $B^{2}$ : quadratical effect of drying time; $S / N$ : Sample number. 
Samples for B5 $\left(52.15^{\circ} \mathrm{C}\right)$ and B7 $\left(67.42^{\circ} \mathrm{C}\right)$ had low pasting temperatures, while the remaining samples showed high pasting temperatures $\left(73.94\right.$ to $\left.95.15^{\circ} \mathrm{C}\right)$. Final viscosity exhibited significant differences $(\mathrm{p}<0.05)$ among all Impilo samples, except samples IM5 (660.33) and IM10 (657.32). On the other hand, differences amongst varieties in final viscosity could be associated with differences in amylose content. Final viscosity was not significantly different $(\mathrm{p}<0.05)$ among all Bophelo samples. Impilo flour (3.94 to $4.69 \mathrm{~min}$ ) indicated a short peak time, while the remaining samples showed a high peak time. Samples B5 (4.98 $\mathrm{min}), \mathrm{B} 7$ (4.53 $\mathrm{min})$ and B10 (4.50 $\mathrm{min})$ showed short pasting times, and the remaining samples of Bophelo indicated long peak times (5.17 to $6.67 \mathrm{~min}$ ). However, values that are low indicate that these all have a low cost implication in terms of electricity usage (Okafor \& Ugwu, 2013).

\subsection{Swelling and solubility of Bophelo (B) and Impilo (IM) flour}

Sample IM13 (8.16 g/g; 13.06 g/g) showed significantly higher swelling and solubility power than the remaining flour samples, as shown in Table 3 and Table 4 . Flour sample B13 (12.45 g/g) showed the highest swelling power and B6 (35.97 g/g) showed high solubility, followed by flours ranging from 29.47 to $21.30 \mathrm{~g} / \mathrm{g}$. Flour which has lower swelling power and solubility causes poor swelling of the baked products (Kusumayanti et al., 2015).

\subsection{Gelatinization parameters of Bophelo (B) and Impilo (IM) flour}

The flour samples for Bophelo and Impilo showed no significant differences $(\mathrm{p}<0.05)$ in all samples in onset and peak temperature (Table 3 and Table 4). Sample B6 $\left(19.65^{\circ} \mathrm{C}\right), \mathrm{B} 13$ $\left(19.47^{\circ} \mathrm{C}\right)$, and samples IM2 $\left(19.32^{\circ} \mathrm{C}\right)$, IM4 (19.41 $\left.{ }^{\circ} \mathrm{C}\right)$, IM6 $\left(19.23{ }^{\circ} \mathrm{C}\right)$ and IM7 $\left(19.29^{\circ} \mathrm{C}\right)$ had high onset gelatinization temperatures $\left(\mathrm{T}_{\mathrm{o}}\right)$, while the remaining samples of Bophelo (B) and Impilo (IM) indicated low T. Flour sample of Bophelo (31.03 to $31.84^{\circ} \mathrm{C}$ ) showed higher peak gelatinization temperatures $\left(\mathrm{T}_{\mathrm{p}}\right)$, while the remaining flour samples showed lower $\mathrm{T}_{\mathrm{p}}$. End gelatinization temperature $\left(\mathrm{T}_{\mathrm{e}}\right)$ of $\mathrm{B} 2\left(55.92^{\circ} \mathrm{C}\right), \mathrm{B} 7\left(60.77^{\circ} \mathrm{C}\right)$ and $\mathrm{B} 13\left(64.47^{\circ} \mathrm{C}\right)$ is lower than for other flour samples, which indicated higher $\mathrm{T}$. However, flour samples IM3 $\left(67.25^{\circ} \mathrm{C}\right)$, IM5 $\left(57.88^{\circ} \mathrm{C}\right), \operatorname{IM} 10\left(56.64^{\circ} \mathrm{C}\right), \operatorname{IM} 11\left(55.57^{\circ} \mathrm{C}\right)$ and $\operatorname{IM} 13\left(66.47^{\circ} \mathrm{C}\right)$ indicated lower $\mathrm{T}$ than other Impilo samples, which showed higher $\mathrm{T}_{e}$, ranging from $93.67^{\circ} \mathrm{C}$ to $97.38^{\circ} \mathrm{C}$. Flour samples B2 and IM5 showed the lowest enthalpy of gelatinization $(\Delta \mathrm{H})$, indicating ease of cooking. The higher $\Delta \mathrm{H}$ means that a higher energy input is required to disrupt their crystalline granules.

\subsection{RSM results for functional properties}

The ANOVA results for these models (Table 2), imply that the developed models can describe the hot air drying process of Impilo and Bophelo flour significantly. The results showed that linear effects of drying temperature and time, interaction effects of drying temperature and time, and quadratic effects of drying temperature and time, all had significant $(\mathrm{p}<0.05)$ effects on the gelatinization parameters. No significant effects were observed on the end temperature $\left(\mathrm{T}_{\mathrm{e}}\right.$ ) and pasting temperature for Bophelo flour. Peak time for both flours showed no significant effects. Regression models relating to the response variables (pasting properties, swelling and solubility index, and gelatinization parameters) and the independent variables (drying

Table 3. Swelling and gelatinization properties of Bophelo at various temperature and time drying conditions.

\begin{tabular}{|c|c|c|c|c|c|c|c|c|}
\hline \multirow[b]{2}{*}{$\mathrm{S} / \mathrm{N}$} & \multicolumn{2}{|c|}{ Independent variables } & \multicolumn{6}{|c|}{ Response variables } \\
\hline & Temperature $\left({ }^{\circ} \mathrm{C}\right)$ & $\begin{array}{l}\text { Time } \\
\text { (hrs) }\end{array}$ & Swelling (g/g) & Solubility $(\mathrm{g} / \mathrm{g})$ & $\mathrm{T}_{\mathrm{o}}\left({ }^{\circ} \mathrm{C}\right)$ & $\mathrm{T}_{\mathrm{p}}\left({ }^{\circ} \mathrm{C}\right)$ & $\mathrm{T}_{\mathrm{e}}\left({ }^{\circ} \mathrm{C}\right)$ & $\Delta \mathrm{H}$ \\
\hline 1 & 70 & 6.5 & $8.15 \pm 0.08^{\mathrm{d}}$ & $21.35 \pm 0.11^{\mathrm{a}}$ & $18.68 \pm 0.47^{\mathrm{bc}}$ & $30.05 \pm 0.20^{\mathrm{bc}}$ & $75.95 \pm 0.36^{c}$ & $168.7 \pm 0.43^{d}$ \\
\hline 2 & 70 & 8.6 & $9.29 \pm 0.32^{c}$ & $25.06 \pm 0.08^{c}$ & $18.44 \pm 0.27^{\mathrm{bc}}$ & $29.34 \pm 0.30^{\mathrm{cd}}$ & $55.92 \pm 0.10^{\mathrm{h}}$ & $61.79 \pm 1.93^{\mathrm{h}}$ \\
\hline 3 & 80 & 5 & $5.68 \pm 0.23^{\mathrm{e}}$ & $18.64 \pm 0.26^{\mathrm{e}}$ & $18.54 \pm 0.02^{\mathrm{bc}}$ & $31.03 \pm 0.32^{\mathrm{ab}}$ & $94.96 \pm 0.10^{\mathrm{b}}$ & $268.09 \pm 0.21^{\mathrm{a}}$ \\
\hline 4 & 70 & 6.5 & $8.18 \pm 0.37^{d}$ & $21.63 \pm 0.36^{\mathrm{d}}$ & $18.45 \pm 0.31^{\mathrm{bc}}$ & $30.85 \pm 0.90^{\mathrm{ab}}$ & $74.64 \pm 0.38^{\mathrm{d}}$ & $168.72 \pm 1.81^{\mathrm{d}}$ \\
\hline 5 & 70 & 4.4 & $3.48 \pm 0.34^{\mathrm{h}}$ & $18.28 \pm 0.42^{\text {ef }}$ & $18.17 \pm 0.01^{c}$ & $31.70 \pm 0.01^{\mathrm{a}}$ & $73.01 \pm 0.83^{\mathrm{e}}$ & $251.30 \pm 0.51^{\mathrm{b}}$ \\
\hline 6 & 80 & 8 & $11.07 \pm 0.11^{\mathrm{b}}$ & $35.97 \pm 0.15^{\mathrm{a}}$ & $19.65 \pm 0.09^{a}$ & $28.12 \pm 0.25^{\mathrm{e}}$ & $95.13 \pm 0.19^{b}$ & $89.09 \pm 0.25^{\mathrm{g}}$ \\
\hline 7 & 60 & 8 & $4.85 \pm 0.20^{\mathrm{f}}$ & $17.98 \pm 0.05^{\mathrm{f}}$ & $18.78 \pm 0.08^{\mathrm{b}}$ & $29.00 \pm 0.74^{\mathrm{ed}}$ & $60.77 \pm 0.61^{\mathrm{g}}$ & $129.08 \pm 0.19^{f}$ \\
\hline 8 & 70 & 6.5 & $8.42 \pm 0.27^{\mathrm{d}}$ & $21.41 \pm 0.35^{\mathrm{d}}$ & $18.60 \pm 0.22^{\mathrm{bc}}$ & $29.43 \pm 0.54^{\mathrm{cd}}$ & $73.39 \pm 0.35^{\mathrm{e}}$ & $169.04 \pm 0.28^{\mathrm{d}}$ \\
\hline 9 & 70 & 6.5 & $8.33 \pm 0.24^{\mathrm{d}}$ & $21.49 \pm 0.31^{\mathrm{d}}$ & $18.68 \pm 0.44^{\mathrm{bc}}$ & $30.62 \pm 0.24^{\mathrm{b}}$ & $73.64 \pm 0.55^{\mathrm{e}}$ & $168.61 \pm 8.31^{\mathrm{d}}$ \\
\hline 10 & 56 & 6.5 & $3.03 \pm 0.08^{\mathrm{i}}$ & $15.98 \pm 0.05^{\mathrm{h}}$ & $18.73 \pm 0.18^{\mathrm{bc}}$ & $29.32 \pm 0.27^{c d}$ & $96.70 \pm 0.88^{\mathrm{a}}$ & $240.87 \pm 0.09^{\mathrm{b}}$ \\
\hline 11 & 60 & 5 & $3.94 \pm 0.17^{g}$ & $17.02 \pm 0.21^{\mathrm{g}}$ & $18.63 \pm 0.27^{\mathrm{bc}}$ & $31.84 \pm 0.40^{\mathrm{a}}$ & $95.83 \pm 0.16^{\mathrm{ab}}$ & $229.44 \pm 0.46^{c}$ \\
\hline 12 & 70 & 6.5 & $8.14 \pm 0.15^{\mathrm{d}}$ & $21.3 \pm 0.41^{\mathrm{d}}$ & $18.49 \pm 0.09^{\mathrm{bc}}$ & $30.55 \pm 0.57^{\mathrm{b}}$ & $75.84 \pm 0.14^{c}$ & $227.15 \pm 17.79^{c}$ \\
\hline 13 & 84 & 6.5 & $12.46 \pm 0.38^{\mathrm{a}}$ & $29.47 \pm 0.42^{\mathrm{b}}$ & $19.47 \pm 0.48^{\mathrm{a}}$ & $31.79 \pm 0.93^{\mathrm{a}}$ & $64.47 \pm 0.40^{\mathrm{f}}$ & $153.01 \pm 0.99^{\mathrm{e}}$ \\
\hline & Model & & $0.0002^{*}$ & $<0.0001$ & $0.0031^{*}$ & $0.0162^{*}$ & 0.3184 & $<0.0001^{*}$ \\
\hline & A-Temperature & & $<0.0001^{*}$ & $<0.0001^{\star}$ & $0.0081^{*}$ & 0.4475 & 0.7627 & 0.1187 \\
\hline & B-Time & & $0.0005^{\star}$ & $<0.0001^{*}$ & $0.0144^{*}$ & $0.0058^{*}$ & 0.1627 & $<0.0001^{*}$ \\
\hline & $\mathrm{A}^{2}$ & & 0.2343 & & $0.0024^{*}$ & & & \\
\hline & $\mathrm{B}^{2}$ & & $0.0113^{*}$ & & 0.2197 & & & \\
\hline & $\mathrm{AB}$ & & $0.0337^{\star}$ & $<0.0001^{*}$ & $0.0329^{*}$ & & 0.2317 & \\
\hline
\end{tabular}

Mean \pm standard deviation; Means with similar superscript letters in a column do not differ significantly $(\mathrm{p} \leq 0.05)$. $\mathrm{T}_{\mathrm{o}}$ onset temperature; $\mathrm{T}$ : peak temperature; $\mathrm{T}$ : end temperature; $\Delta \mathrm{H}$ : enthalpy of gelatinization; A: direct effect of drying temperature; B: direct effect of drying time; $\mathrm{AB}$ : effect of drying temperature and drying time; $\mathrm{A}^{2}$ : quadratical effect of drying temperature; $B^{2}$ : quadratical effect of drying time; S/N: Sample number. 
temperature and time) are given in Table 5 and Table 6 , respectively. The quadratic, linear, reduced quadratic and quadratic models best explain the functional relationships between the processing variables and pasting properties, swelling and solubility index, and gelatinization parameters for both flours. The coefficient of determination $\left(\mathrm{R}^{2}\right)$ of models was relatively high, ranging from
0.51-0.98. This is an extensively used measure to determine the goodness of fit of a regression model. The value of $\mathrm{R}^{2}$ varies from 0 to 1 ; however, the value close to 1 is the better fit for a regression model (Omolola et al., 2015). For both cultivars, drying time (B) had the most linear effect on pasting properties, swelling and solubility index, and gelatinization parameters.

Table 4. Swelling and gelatinization properties for Impilo flour at various temperature and time drying conditions.

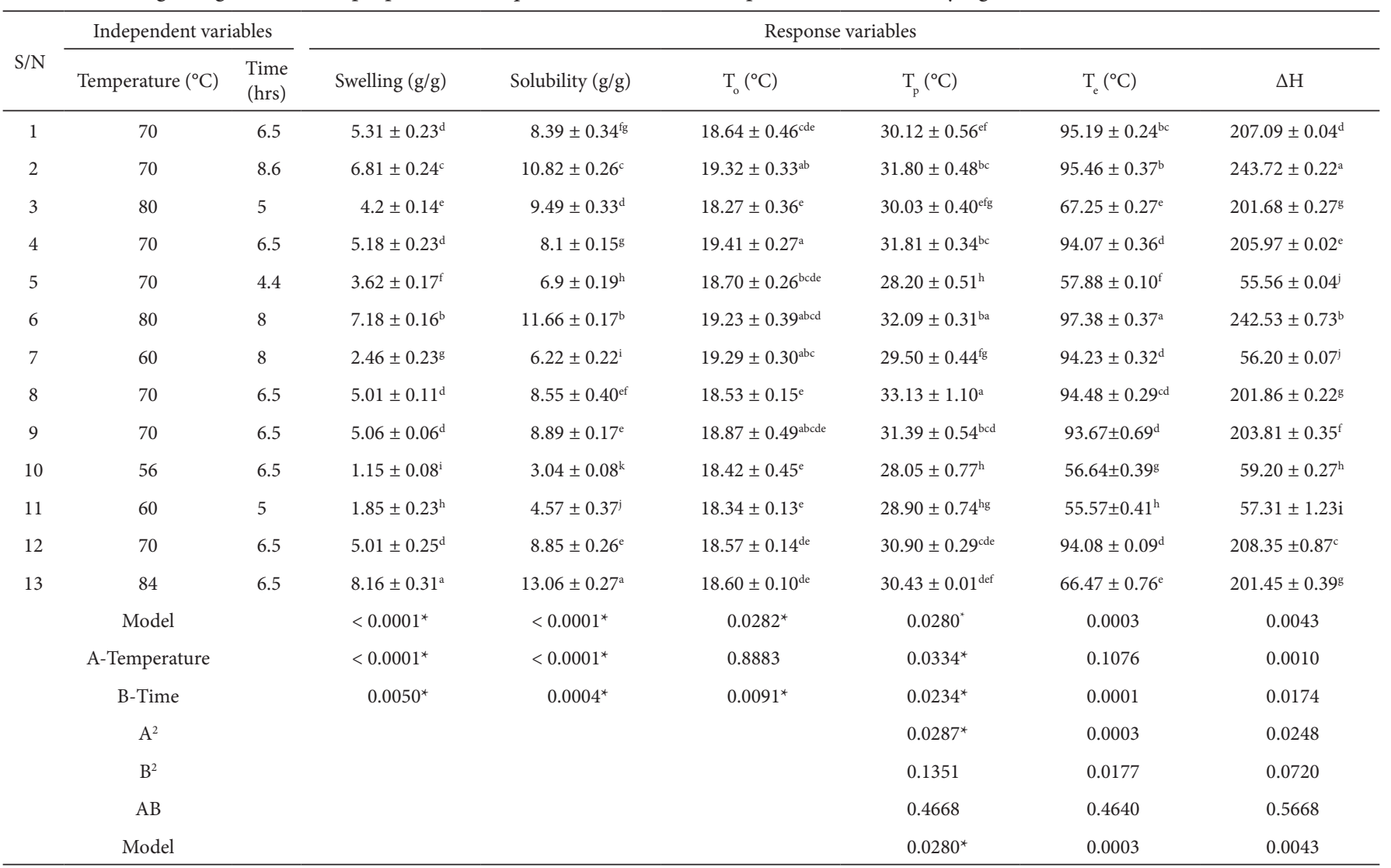

Mean \pm standard deviation; Means with similar superscript letters in a column do not differ significantly $(\mathrm{P}<0.05) ; \mathrm{T}_{\mathrm{o}}$ onset temperature; $\mathrm{T}_{\mathrm{p}}$ : peak temperature; $\mathrm{T}_{e}$ : end temperature; $\Delta \mathrm{H}$ enthalpy of gelatinization. ${ }^{*}$ Significant at $\mathrm{p}<0.05$. A: direct effect of drying temperature; $\mathrm{B}$ : direct effect of drying time; $\mathrm{AB}$ : effect of drying temperature and drying time; $\mathrm{A}^{2}$ : quadratical effect of drying temperature; $\mathrm{B}^{2}$ : quadratical effect of drying time; S/N: Sample number.

Table 5. Regression models relating response variables and independent variables for Bophelo flour.

\begin{tabular}{|c|c|c|}
\hline Variables & Models & $\mathrm{R}^{2}$ \\
\hline Peak Viscosity $(\mathrm{cP})$ & $-21461.00579+447.02972 \star \mathrm{A}+2263.34584^{\star} \mathrm{B}-3.28902^{\star} \mathrm{A}^{2}-181.47507^{\star} \mathrm{B}^{2}+1.14444^{\star} \mathrm{A} * \mathrm{~B}$ & 0.98 \\
\hline Trough $(\mathrm{cP})$ & $-19124.76725+398.83716^{\star} \mathrm{A}+1999.58452 * \mathrm{~B}-2.95131{ }^{\star} \mathrm{A}^{2}-163.91009 * \mathrm{~B}^{2}+1.66667{ }^{\star} \mathrm{A} * \mathrm{~B}$ & 0.98 \\
\hline Breakdown $(\mathrm{cP})$ & $+378.03266-9.83778 * A+21.77843 * \mathrm{~B}+0.11928^{\star} \mathrm{A}^{2}+5.37533^{\star} \mathrm{B}^{2}-1.35000 * \mathrm{~A} * \mathrm{~B}$ & 0.90 \\
\hline Final Viscosity $(\mathrm{cP})$ & $-13615.14184+267.02556 * A+1763.14493 * B-2.03770 * A^{2}-149.08276 * B^{2}+2.27222 * A * B$ & 0.92 \\
\hline Setback (cP) & $-4396.91395+79.52943{ }^{\star} \mathrm{A}+629.10618^{\star} \mathrm{B}-0.59820 * \mathrm{~A}^{2}-51.91977{ }^{\star} \mathrm{B}^{2}+0.63889 * \mathrm{~A} * \mathrm{~B}$ & 0.88 \\
\hline Peak Time (cP) & +5.51615 & 0.00 \\
\hline Peak Temperature $(\mathrm{cP})$ & +76.29205 & 0.00 \\
\hline $\mathrm{T}_{\mathrm{o}}\left({ }^{\circ} \mathrm{C}\right)$ & $+36.80452-0.51552{ }^{*} \mathrm{~A}-0.43790{ }^{*} \mathrm{~B}+3.11875 \mathrm{E}-003 * \mathrm{~A} 2-0.040278{ }^{*} \mathrm{~B} 2+0.015667^{*} \mathrm{~A} * \mathrm{~B}$ & 0.89 \\
\hline $\mathrm{Tp}\left({ }^{\circ} \mathrm{C}\right)$ & $+33.51119+0.025721 * \mathrm{~A}-0.75730 * \mathrm{~B}$ & 0.56 \\
\hline $\mathrm{Te}\left({ }^{\circ} \mathrm{C}\right)$ & $+386.57069-3.96771 * \mathrm{~A}-46.02324^{\star} \mathrm{B}+0.58717^{*} \mathrm{~A} * \mathrm{~B}$ & 0.31 \\
\hline$\Delta \mathrm{H}(\mathrm{J} / \mathrm{g})$ & $+578.01045-1.56991 * \mathrm{~A}-45.59275^{*} \mathrm{~B}$ & 0.85 \\
\hline Swelling & $-25.48151+0.36817^{\star} \mathrm{A}+2.33572^{\star} \mathrm{B}-4.19500 \mathrm{E}-003^{\star} \mathrm{A} 2-0.48867^{\star} \mathrm{B} 2+0.074667^{\star} \mathrm{A} * \mathrm{~B}$ & 0.95 \\
\hline Solubility & $+97.15430-1.28982^{*} \mathrm{~A}-16.77514^{*} \mathrm{~B}+0.27283^{*} \mathrm{~A}{ }^{*} \mathrm{~B}$ & 0.96 \\
\hline
\end{tabular}

$\mathrm{T}_{\mathrm{o}}$ onset temperature; $\mathrm{T}_{\mathrm{p}}$ : peak temperature; $\mathrm{T}_{\mathrm{e}}$ : end temperature; $\Delta \mathrm{H}$ : enthalpy of gelatinization. $\mathrm{A}$ : direct effect of drying temperature; $\mathrm{B}$ : direct effect of drying time. 
However, drying temperature had the most quadratic effect on onset temperature $\left(\mathrm{T}_{\mathrm{o}}\right.$ ) for Bophelo flour, and also for the pasting temperature for Impilo flour.

The results for optimized drying conditions for Bophelo were $67.53^{\circ} \mathrm{C}$ for $6.71 \mathrm{hrs}$ and $66.88^{\circ} \mathrm{C}$ for $5.04 \mathrm{hrs}$, and for Impilo $69.35^{\circ} \mathrm{C}$ for $6.87 \mathrm{hrs}$ and $61.57^{\circ} \mathrm{C}$ for 5.94 hrs. Desirability of the obtained optimum conditions were 1.00 for Bophelo and Impilo flour. These results indicate that drying of Bophelo and Impilo at the optimized drying conditions will give good functional properties to the flour. Response surface plots of pasting properties, gelatinization parameters, swelling and solubility index are shown in Fig. 1 and Fig. 2 for Bophelo and Impilo flour, respectively. It is clear from the figures that there are variations within the shape of the response surface plots obtained for Bophelo and Impilo and these variations may be attributed to the result of the OFSP cultivar selection and processing conditions.

Table 6. Regression models relating response variables and independent variables for Impilo flour.

\begin{tabular}{|c|c|c|}
\hline Variables & Models & $\mathrm{R}^{2}$ \\
\hline Peak Viscosity (cP) & $9606.12162+109.08483 * A+1939.29540 \star B-0.55210 * A^{2}-128.42566{ }^{\star} B^{2}-3.51667 * A * B$ & 0.83 \\
\hline Trough $(\mathrm{cP})$ & $10386.83667+173.50901 * A+1517.49137 * B-0.89355 * A^{2}-85.52770 * B^{2}-6.17778 * A * B$ & 0.86 \\
\hline Breakdown $(\mathrm{cP})$ & $+2459.36943-40.11111^{*} \mathrm{~A}-276.62279 * \mathrm{~B}+0.21848^{*} \mathrm{~A}^{2}+14.96955 * \mathrm{~B}^{2}+1.07222 * \mathrm{~A} * \mathrm{~B}$ & 0.91 \\
\hline Final Viscosity $(\mathrm{cP})$ & $-24626.67447+521.79102 \star A+2360.95725^{\star} \mathrm{B}-3.32238^{\star} \mathrm{A}^{2}-140.14165^{\star} \mathrm{B}^{2}-8.16111^{\star} \mathrm{A}{ }^{\star} \mathrm{B}$ & 0.85 \\
\hline Setback $(\mathrm{cP})$ & $-6248.41121+130.76265 * A+630.02372 \star B-0.83004 * A^{2}-37.40926 * B^{2}-2.15000 * A * B$ & 0.85 \\
\hline Peak Time (cP) & +4.95231 & 0.00 \\
\hline Peak temperature $(\mathrm{cP})$ & $-232.19116+8.667833^{\star} \mathrm{A}+3.46946^{\star} \mathrm{B}-0.050611^{\star} \mathrm{A}^{2}+1.35654^{\star} \mathrm{B}^{2}-0.27917^{\star} \mathrm{A}{ }^{\star} \mathrm{B}$ & 0.70 \\
\hline $\mathrm{T}_{\mathrm{o}}\left({ }^{\circ} \mathrm{C}\right)$ & $+17.16533+1.55698 \mathrm{E}-003 * \mathrm{~A}+0.23223{ }^{\star} \mathrm{B}$ & 0.51 \\
\hline $\mathrm{T}_{\mathrm{p}}\left({ }^{\circ} \mathrm{C}\right)$ & $-27.65198+1.31291 * \mathrm{~A}+2.45260 * \mathrm{~B}-9.87500 \mathrm{E}-003 * \mathrm{~A}^{2}-0.27000 * \mathrm{~B}^{2}+0.024333 * \mathrm{~A} * \mathrm{~B}$ & 0.78 \\
\hline $\mathrm{T}_{\mathrm{e}}\left({ }^{\circ} \mathrm{C}\right)$ & $-868.40017+20.88008 * A+57.32335 * B-0.13998^{*} A^{2}-2.86233 * B^{2}-0.14217 * A * B$ & 0.94 \\
\hline$\Delta \mathrm{H}(\mathrm{J} / \mathrm{g})$ & $-2480.20368+54.85981 * A+138.46192 * B-0.37684 * A^{2}-12.45606 * B^{2}+0.69933 * A * B$ & 0.88 \\
\hline Swelling & $-14.55660+0.21230 * \mathrm{~A}+0.67511$ * $\mathrm{B}$ & 0.87 \\
\hline Solubility & $-18.18690+0.30663 * \mathrm{~A}+0.78031 * \mathrm{~B}$ & 0.95 \\
\hline
\end{tabular}

$T_{o:}$ onset temperature; $T_{p}$ : peak temperature; $T_{e}$ : end temperature; $\Delta \mathrm{H}$ : enthalpy of gelatinization. A: direct effect of drying temperature; $\mathrm{B}$ : direct effect of drying time.
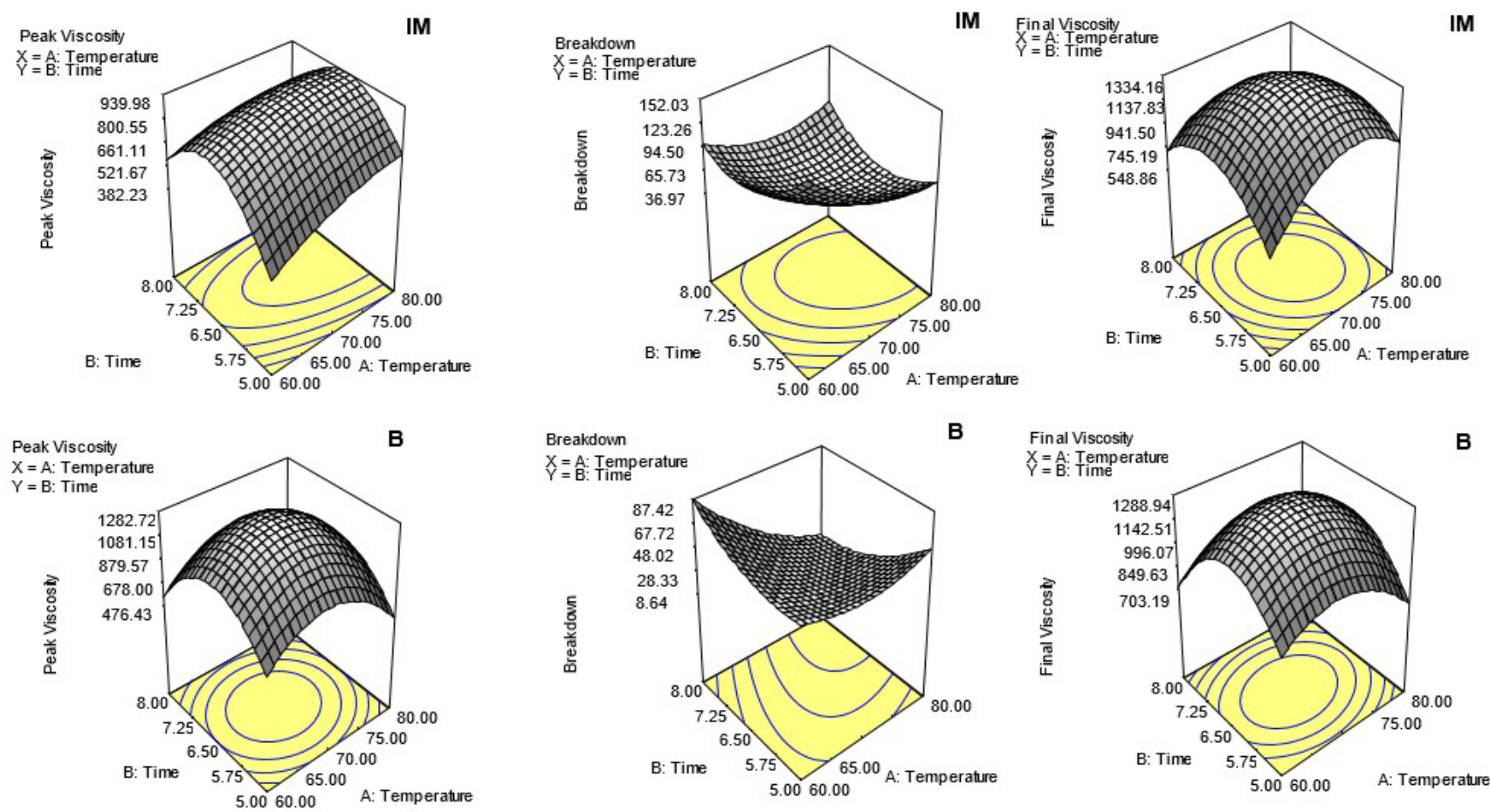

Figure 1. Response surface plot showing the effect of drying temperature and drying time on pasting properties of Bophelo (B) and Impilo (IM) orange-fleshed sweet potato. 

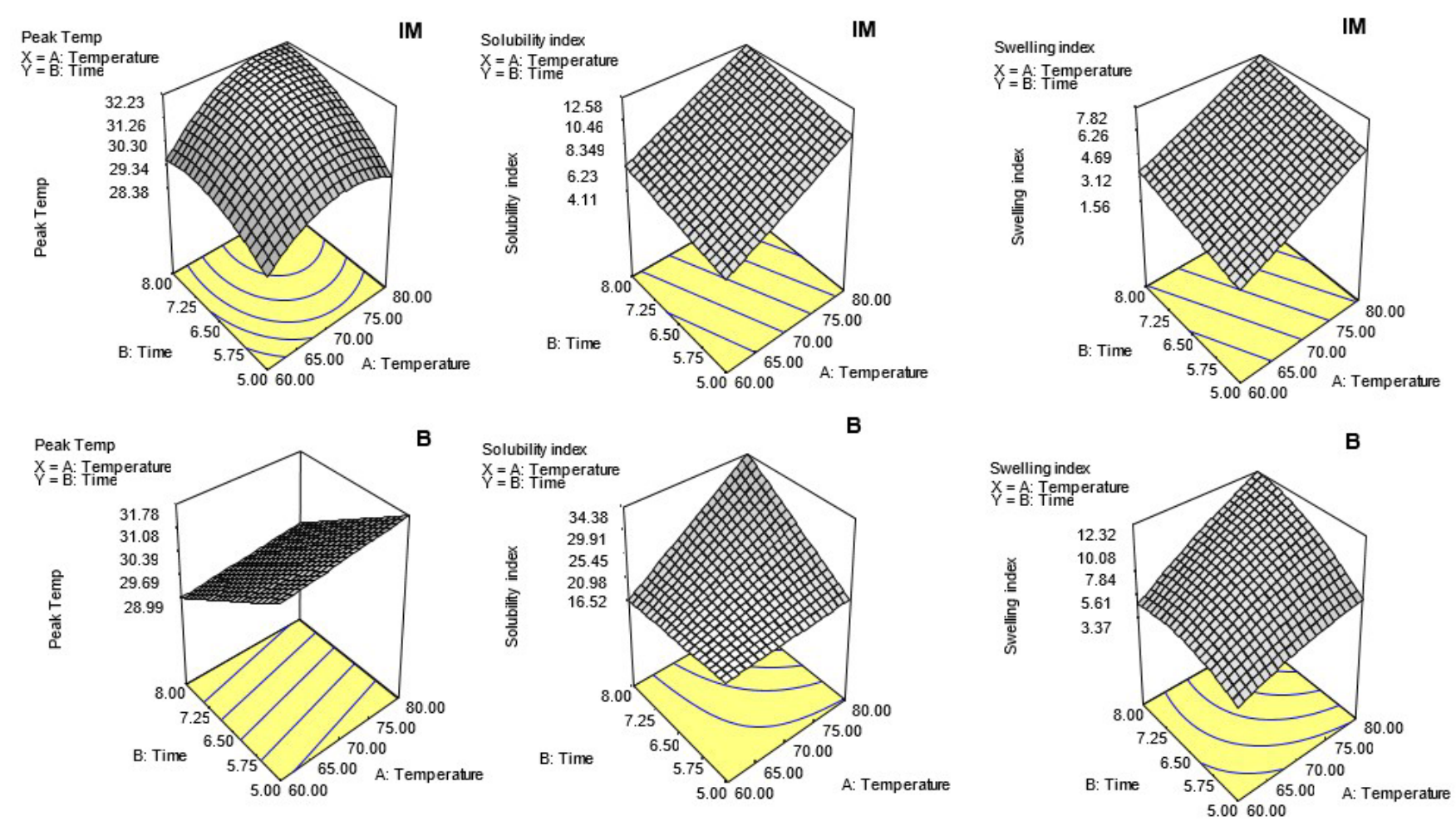

Figure 2. Response surface plot showing the effect of drying temperature and drying time on gelatinisation parameters, swelling and solubility index of Bophelo (B) and Impilo (IM) orange-fleshed sweet potato.

\section{Conclusions}

Variations in the functional properties of the two flours of the two different OFSP cultivars were examined and the effect of an electric hot-air cabinet dryer on the functional properties was investigated. The findings suggest that the final viscosity values of flour from all of the flour samples were higher than their corresponding peak viscosity and trough values. Flour samples for all cultivars that were exposed to high drying temperatures and time showed high swelling and solubility properties, indicating that these can be potentially used for baked products. Flour for Bophelo and Impilo at drying temperatures and times of $70^{\circ} \mathrm{C}$ for $4.4 \mathrm{hrs}, 56^{\circ} \mathrm{C}$ for $6.5 \mathrm{hrs}$ and $60^{\circ} \mathrm{C}$ for $6.5 \mathrm{hrs}$ showed good gelling power and a low cost implication, implying that these can be used in food processing at household level and for industrial purposes. Drying conditions of Bophelo at $67.53^{\circ} \mathrm{C}$ for $6.71 \mathrm{hrs}$ and at $66.88^{\circ} \mathrm{C}$ for $5.04 \mathrm{hrs}$, and of Impilo at $69.35^{\circ} \mathrm{C}$ for $6.87 \mathrm{hrs}$ and at $61.57^{\circ} \mathrm{C}$ for $5.94 \mathrm{hrs}$ were found optimum for product quality at a desirability of 1.00 . OFSP flour can be processed from South African sweet potato cultivars Bophelo and Impilo as part of the global effort to promote the utilisation of OFSP.

Drying of produce is beneficial because it extends shelf life, produces microbiologically safe food, with minimal degradation of nutrient and sensory properties. OFSP is rich in $\beta$-carotene, a precursor of vitamin $\mathrm{A}$, but with limited use locally. Thus, promoting utilization of OFSP through processing would contribute towards food security, nutrition security and increased food variety.

\section{Acknowledgements}

The authors are thankful to the National Research Foundation (NRF) of South Africa for funding the studies (Grant no. 96651), the Agricultural Research Council for financial support of the visits to the University of Venda, and the University of Venda for financial support through the Work Study Program (SARDF/16/FST/06).

\section{References}

Abdulla, G., El-Shourbagy, G. A., \& Sitohi, M. Z. (2014). Effect of predrying, blanching and citric acid treatments on the quality of fried sweet potato chips. American Journal of Food Technology, 9, 39-48. http://dx.doi.org/10.3923/ajft.2014.39.48.

Adebowale, Y. A., Adeyemi, A., \& Oshodi, A. A. (2005). Functional and physicochemical properties of flours of six Mucuna species. African Journal of Biotechnology, 4, 1461-1468.

Ahmed, M., Akter, M. S., \& Eun, J. B. (2010). Peeling, drying temperatures, and sulphite-treatment affect physicochemical properties and nutritional quality of sweet potato flour. Food Chemistry, 121(1), 112-118. http://dx.doi.org/10.1016/j.foodchem.2009.12.015.

Aina, A. J., Falade, K. O., Akingbala, J. O., \& Titus, P. (2009). Physicochemical properties of twenty one Caribbean sweet potato cultivars. International Journal of Food Science \& Technology, 44(9), 1696-1704. http://dx.doi.org/10.1111/j.1365-2621.2009.01941.x.

Akinoso, R., \& Adeyanju, J. A. (2012). Optimization of edible oil extraction from Ofada rice bran using response surface methodology. Food and Bioprocess Technology: An International Journal, 5(4), 1372-1378. http://dx.doi.org/10.1007/s11947-010-0456-8. 
Allen, J. C., Corbitt, A. D., Maloney, K. P., Butt, M. S., \& Truong, V. D. (2012). Glycemic index of sweet potato as affected by cooking methods. The Open Nutrition Journal, 6(1), 1-11. http://dx.doi.org /10.2174/1874288201206010001.

Esan, T. A., Sobukola, O. P., Sanni, L. O., Bakare, H. A., \& Munoz, L. (2015). Process optimization by response surface methodology and quality attributes of vacuum fried yellow fleshed sweetpotato (Ipomoea batatas L.) chips. Food and Bioproducts Processing, 95, 27-37. http://dx.doi.org/10.1016/j.fbp.2015.03.008.

Fetuga, G., Tomlins, K., Henshaw, F., \& Idowu, M. (2014). Effect of variety and processing method on functional properties of traditional sweet potato flour ("elubo") and sensory acceptability of cooked paste (“amala"). Food Science \& Nutrition, 2(6), 682-691. http:// dx.doi.org/10.1002/fsn3.161. PMid:25493186.

Kamal, M. S., Islam, M. N., \& Aziz, M. G. (2013). Effect of sweet potato flour of two local varieties on quality of breads. Journal of the Bangladesh Agricultural University, 11(2), 301-306. http://dx.doi. org/10.3329/jbau.v11i2.19929.

Kusumayanti, H., Handayani, N. A., \& Santosa, H. (2015). Swelling power and water solubility of cassava and sweet potatoes flour. Procedia Environmental Sciences, 23, 164-167. http://dx.doi.org/10.1016/j. proenv.2015.01.025.

Manjarres-Pinzon, K., Cortes-Rodriguez, M., \& Rodríguez-Sandoval, E. (2012). Effect of drying conditions on the physical properties of impregnated orange peel. Brazilian Journal of Chemical Engineering, 30(3), 667-676. http://dx.doi.org/10.1590/S0104-66322013000300023.

Mohamed, A. A., Alamri, M. S., Hussain, S., Ibraheem, M. A. R., \& Qasem, A. A. (2019). Rheological properties of sweet potato starch-date syrup gel. Food Science and Technology, 39(4), 1030-1039. http:// dx.doi.org/10.1590/fst.16618.

Nabubuya, A., Namutebi, A., Byaruhanga, Y., Judith Narvhus, J., \& Wicklund, T. (2012). Potential use of selected sweet potato (Ipomoea batatas Lam) varieties as defined by chemical and flour pasting characteristics. Food and Nutrition Sciences, 3(07), 889-896. http://dx.doi.org/10.4236/fns.2012.37118.

Okafor, C. C., \& Ugwu, E. E. (2013). Comparative study of pasting properties of high fibre plantain based flour intended for diabetic food (Fufu). World Academy of Science. Engineering and Technology International Journal of Nutrition and Food Engineering, 7, 494-498.

Oke, M. O., \& Workneh, T. S. (2013). A review on sweet potato postharvest processing and preservation technology. African Journal of Agricultural Research, 8, 4990-5003.
Olutande, G. O., Jideani, A. I. O., Kapila, P. F., \& Jideani, V. A. (2016). Quality attributes of sweet potato flour as influenced by variety, pretreatment and drying method. Food Science \& Nutrition, 4(4), 623-635. http://dx.doi.org/10.1002/ fsn3.325. PMid:27386111.

Omolola, A. O., Jideani, A. I. O., Kapila, P. F., \& Jideani, V. A. (2015). Optimization of microwave drying conditions of two banana varieties using response surface methodology. Food Science and Technology, 35(3), 438-444. http://dx.doi.org/10.1590/1678-457X.6700.

Owade, J. O., Abong, G. O., \& Okoth, M. W. (2018). Production, utilization and nutritional benefits of orange-fleshed sweetpotato (OFSP) puree bread: A review. Current Research in Nutrition and Food Science, 6(3), 1-12. http://dx.doi.org/10.12944/ CRNFSJ.6.3.06.

Parker, M. L., Low, J. W., \& Andrade, M. I. (2019). Climate change and seed systems of roots, tubers and bananas: The cases of potato in Kenya and sweet potato in Mozambique: investigating the business of a productive, resilient and low emission future. In T. Rosenstock, A. Nowak \& E. Girvetz (Eds.), The climate-smart agriculture papers investigating the business of a productive, resilient and low emission future (pp. 99-111). Cham: Springer. http://dx.doi.org/10.1007/9783-319-92798-5_9.

Rohaya, M. S., Maskat, M.Y., \& MA’aruf, A. G. (2013). Rheological properties of different degree of pre-gelatinized rice flour batter. Sains Malaysiana, 42, 1707-1714.

Rufus, R. D. (2012). Effects of pre-treatments on drying kinetics of sweet potato slices. Agricultural Engineering International: CIGR Journal, 14, 136-145.

Shimelis, A. E., Meaza, M., \& Rakshit, S. (2006). Physico-chemical properties, pasting behaviour and functional characteristics of flours and starches from improved bean (Phaseolus vulgaris L.) varieties grown in East Africa. Agricultural Engineering International: CIGR Journal, 8, 1-18.

Singh, J., McCarthy, O. J., \& Singh, H. (2006). Physico-chemical and morphological characteristics of New Zealand Taewa (Maori potato) starches. Carbohydrate Polymers, 64(4), 569-581. http://dx.doi. org/10.1016/j.carbpol.2005.11.013.

Singh, S., Raina, C. S., Bawa, A. S., \& Saxena, D. C. (2004). Sweet potato-based pasta product: optimization of ingredient levels using response surface methodology. International Journal of Food Science \& Technology, 39(2), 191-200. http://dx.doi.org/10.1046/j.09505423.2003.00764.x. 